\title{
Indicators of Sustainable Use of Wildlife: Problems of Formation and Implementation in the Russian Federation
}

\section{Wskaźniki zrównoważonego użytkowania dzikiej przyrody: problemy związane $\mathrm{z}$ ich formowaniem i wdrażaniem w Federacji Rosyjskiej}

\author{
Svetlana Ivanova \\ Orenburg State Agrarian University, Land Law and Labor Law Department, Orenburg, \\ Russian Federation \\ Home address: 12, ul. Ozernaya, Prigorodny Settlement, Orenburg District, Orenburg Re- \\ gion, 460507, Russian Federation \\ E-mail: svetlana.ivanova.osau@gmail.com
}

\begin{abstract}
This article examines the legal category sustainable use of wildlife as a process of realization of rights and obligations by the subjects, based on the provisions of the Concept of Sustainable Development, International law and National legislation on wildlife. This process is aimed at ensuring biological diversity, achieving a balance of economic, environmental and social interests of the citizens, society and the state as a whole, the process, as well as to preserve the reproductive ability of the animal world.

Based on the analysis of certain provisions of the legislation on wildlife and law enforcement practice, the author makes a conclusion that Russia lacks a complex system of legal support measures for the sustainable use of wildlife. Legal, economic, ideological, organizational measures, proposed by the author of the article will make it possible to use wildlife in such a way, that will preserve and increase the number of wildlife populations, maintain an ecological balance, and ensure the needs in favorable environment for life and health for the present and future generations. The measures proposed by the author can create the legal basis for sustainable management of wildlife. The author suggests, that these measures can be useful in developing national programs for sustainable use of wildlife; providing incentives for the transition to sustainable use; strengthening the dialogue between the authorities and the population in order to involve them into the process of sustainable use of wildlife, so that to ensure a balance of economic, environmental and social interests.
\end{abstract}

Key words: wildlife, sustainable use of wildlife, legal support measures, conservation of biodiversity of wildlife, environmental balance, public and private interests

\footnotetext{
Streszczenie

Artykuł analizuje kategorię prawną zrównoważone użytkowanie dzikiej przyrody rozumianą jako proces realizacji praw i obowiązków przez podmioty, w oparciu o postanowienia koncepcji zrównoważonego rozwoju, prawa międzynarodowego i ustawodawstwa krajowego dotyczącego dzikiej przyrody. Proces ma na celu zapewnienie różnorodności biologicznej, osiągnięcie równowagi interesów ekonomicznych, środowiskowych i społecznych obywateli, społeczeństwa i państwa jako całości oraz zachowanie zdolności reprodukcyjnych świata zwierząt.

Na podstawie analizy niektórych przepisów dotyczących dzikiej fauny i flory i oceny realizowania tych zapisów w praktyce, autorka stwierdza, że w Rosji brakuje kompleksowego systemu prawnych środków wsparcia dla zrównoważonego użytkowania dzikiej przyrody. Zaproponowane przez autorkę artykułu rozwiązania prawne, ekonomiczne i organizacyjne umożliwią korzystanie z dzikiej przyrody w taki sposób, który zachowa i zwiększy liczbę populacji dzikich zwierząt, utrzyma równowagę ekologiczną i zapewni zaspokojenie potrzeb życia i zdrowia dla
} 
obecnych i przyszłych pokoleń, w korzystnym środowisku. Środki zaproponowane przez autorkę mogą stworzyć podstawę prawną dla zrównoważonego zarządzania dziką przyrodą. Autorka sugeruje, że rozwiązania te mogą być przydatne w opracowywaniu krajowych programów zrównoważonego użytkowania dzikiej przyrody; zapewniania zachęt do przejścia na zrównoważone użytkowanie; wzmocnienia dialogu między władzami a ludnością w celu włączenia ich w proces zrównoważonego wykorzystywania dzikiej fauny i flory, aby w ten sposób zapewnić równowagę interesów gospodarczych, środowiskowych i społecznych.

Słowa kluczowe: dzika przyroda, zrównoważone użytkowanie dzikiej przyrody, środki pomocy prawnej, ochrona bioróżnorodności dzikiej przyrody, równowaga ekologiczna, interesy publiczne i prywatne

\section{Introduction}

Wildlife is an integral part of different biological diversities and thus is one of the conditions for solving problems and achieving the environmentally oriented development. Environmental protection is not an absolute value and environmental requirements should be set at a level that does not impede the economic growth. In fact, it is a question of implementing the concept of sustainable development, stated in the international document Our Common Future and, therefore, implemented in the international treaties of the Russian Federation on environmental protection and the sustainable use of its components. Thus, ensuring sustainable use of wildlife is a strategic task, which is also aimed at realizing Russia's international obligations. The efficient economic development as well as the present and future generations welfare strongly depend on the proper implementation of this task. In order to complete the task, first of all, it is necessary to form an effective legal tool kit. With the help of a set of legal measures, it is possible to organize such use of the animal world that will save and increase the number of wild animal populations, maintain the ecological balance in nature, and ensure the satisfaction of the present and future generations needs. Ensuring the sustainable use of wildlife is one of the acute issues of the modern world, requiring urgent resolution at the international and national levels.

According to the report on the current environmental situation adopted in 2016, one in eight bird species, one in four mammal species, every third amphibian species, and six out of seven species of sea turtles (State report, 2016) are currently threatened with extinction. According to the WWF Living Planet report, the average annual decline in the number of mammals, birds, and fish populations is $2 \%$. Currently, there are no signs of a slowdown in this process. If these trends continue, then by 2020 the number of populations will decrease by two-thirds (67\%) (WWF's Living Planet Report, 2016). Over the past 30 years the flying insects population of the nature reserves and national parks in Germany, decreased by $75 \%$. Wherein, the main threats to the animal world and its habitat are directly related to human activities. The environmental consequences of human activities are increasingly exceeding the biological assimilation potential of the Earth, which ultimately leads to the extinction of wildlife. All this, according to experts, can lead to an irreplaceable loss of biodiversity on a large territory of the earth by the middle of the 21 st century. Scientists from the University of Sydney and the Chinese Academy of Agricultural Sciences have analyzed 73 studies from different countries over the past 40 years on reducing insect populations and published a report (SanchezBayoa, Wyckhuysbn, 2019). According to them, the total biomass of insects is reduced by 2.5 percent per year, which means that insects can disappear during this century.

The National Environment Commission claims that only a healthy economy can provide the resources needed to invest in environmental protection. For this reason, sustainable development aims at a decent standard of living for all, combined with maintaining the integrity of all ecological systems. Of particular importance in this situation is the doctrinal development of the concept of sustainable use, provided through legal, economic, ideological, organizational measures. These measures will achieve a balance of interests between society, business and the state.

In this regard, the opinions and decisions proposed in this article can be used by the representative and executive bodies of the state power in Russia and the CIS countries in the development of new plans and strategies in the field of sustainable use and conservation of wildlife. This article may also be of interest to environmental lawyers engaged in research on the sustainable development of sustainable use of wildlife and the conservation of wildlife, as well as ordinary citizens who are interested in the environmental consequences of human activities, which pose a threat to the animal world and its environment.

\section{Sustainable Use of Wildlife: a Process or a State}

Based on international law, all states have the sovereign right to dispose of their natural resources in accordance with their environmental policy. States are responsible for ensuring that any economic activity carried out on their territory or under their control does not cause any significant damage to the nature of other states outside the borders of national jurisdiction. States are also responsible for the sustainable and safe use of natural resources, including natural resources exclusively on their own territory, in order to promote the development of their peoples, paying particular attention to the rights of indigenous peoples, as well as the conservation and sustainable 
use of natural resources. Thus, almost all countries of the world recognize the need for sustainable use of biological diversity. To ensure this use, states adopt strategic planning documents at the international level and carry out other actions aimed at resolving issues related to the conservation of natural resources. Wild animals living within the territorial borders of the state are under their sovereignty and are their property. Thus, it is very important for each state to provide legal support for the sustainable use wildlife timely and efficiently, since the condition of this component of the natural environment on the globe will mainly depend on this (Kolbasov, 1982). At the present stage, the necessary task of states is to establish international cooperation to solve the complex problem of the sustainable use and conservation of certain species of the animal world, their habitat, as well as all biodiversity in natural ecological systems.

Russia plays a leading role in maintaining global biodiversity through conservation of natural ecological systems, combined with a significant part of the world's species diversity. In the modern world, under the influence of negative anthropogenic factors on natural objects, including the objects of animal world, full and comprehensive ensuring of the sustainable use of wildlife is possible only by applying a whole range of measures for this sustainable use, reproduction and conservation. There appears a need for a comprehensive study of different aspects in the protection and use of wildlife in order to develop interrelated measures aimed at ensuring the sustainable use of wildlife. The need for legal support for the sustainable use of wildlife is directly related to the satisfaction of the material and spiritual needs of all people on the planet. Thus, nowadays there is no doubt that the implementation of sustainable use of wild animals is of great importance for the whole mankind.

According to some authors, the sustainable use wildlife should be regarded as an ongoing process, and not a state, which must be sought. This happens because the ecological knowledge of the species and populations used, on the one hand, and the socioeconomic knowledge of wildlife, on the other hand, remain uncertain. This is due to the fact that economic, environmental and social requirements for the use of the animal world change in time. In order for the use to be sustainable, public administration of the animal world should comply with new requirements, standards, and criteria in the field of its use. So, the question of whether a particular use is sustainable or not can be answered by analyzing the past (Webb, 2002). From this point of view, sustainability can be considered only as a process supported for a certain period time. Probably, sustainability requires not only the study of environmental information, but also the ability of the existing wildlife management system to meet and adapt to new changes.
This suggests that the given characteristic of the sustainable use of the animal world can be much more important than a detailed study of each object of the animal world and their interaction within the environmental system. Such treatment of sustainability as a process means that it is impossible to determine whether the use is sustainable or not at a specific (given) time section. The only thing that can be determined is whether the use has been sustainable until now, and what is the probability of the use to be more or less sustainable in future.

However, this position is definitely of great importance for the legislation and state environmental policy, for which it is necessary to have evidence that the use is sustainable before allowing it in future.

This view is widely supported by most of the key policy documents on sustainable use. So, according to the White Oak principles of SU, sustainable use is a dynamic process, not a state. This position is also supported in the Analytical Framework 2001 (Moncrieffe, Luttrell, 2005). The Africa Adaptation Program emphasizes the dynamism of this process: sustainable use is not a fixed state, but rather a consequence of balancing a wide range of factors that vary depending on the context of use. More than that, the sustainability of use cannot be regarded as definite, but it is rather probable, since it can change if the conditions under which the management is carried out change. The IUCN experts on sustainable use state that the enhancement of the wildlife sustainable use is a long time process of improved management of these resources. Although this value is not entirely clear, it is certainly interpreted in support of the concept of sustainable use of the animal world as a process, not a state. It is in the process of sustainable use that the requirements of the rule of law are transferred into practical life.

The study of the institutional meaning of the concept sustainable use of wildlife is of significant importance, which is due to the harmonization of all its components (economic, social and environmental), which allows to meet the needs of society and the state. This study becomes very important at the present stage of development of legal regulation of relations in the field of wildlife protection and use.

Global environmental problems associated with such negative processes as loss of biological diversity, climate change, desertification, deforestation, water pollution, the consequences of natural and technological disasters directly affect the state interests of the Russian Federation and the interests of its citizens. Therefore, the sustainable use of the animal world is to some extent connected with the needs and interests of the state and society.

Thus, sustainable use of the animal world should be defined as a process of exploitation and consumption of the animal world resources, i.e. the components of natural environment that can be removed by humans for their needs. This process is subject to legal regulation by the norms of various industry affiliations. 
That is why sustainable use of the animal world is so diverse in character.

\section{A Variety of Legal Support Measures: Prob- lems of Their Implementation in Russia}

According to M.N. Marchenko, the concept of legal measures (means) allows to summarize all those phenomena which are designed to achieve the goals set in the legislation (Marchenko, 2001). V. A. Sapun notes that the main purpose of legal measures is to show what social problems can be solved through these legal mechanisms, where and how they can be used in practical legal activities to achieve socially significant results (Sapun, 1992). Thus, the concept legal measures, which help to provide sustainable use of the wildlife includes the idea of sustainable use of the animal world as a model of subjects behavior, stated in the legislation on the animal world, aimed at achieving the optimal balance of interests between society and the state.

In order to ensure the sustainable use of the animal world, to preserve its habitat, to maintain the functioning of natural environmental systems, the norms of legislation on the animal world are designed to affect the subjects of legal relations. The result of such influence is a balance of interests between society and state. The main legal tool kit of legal regulation is legal documents. Legal documents are regarded as a place where the that primary legal norms and rules of conduct are stated, which represent the starting point for the means of action (technology), legal awareness, existence and realization of law. Legal documents help to achieve the sustainability of relations in the use of wildlife. Such legal documents comprise normative legal acts, documents containing decisions of an individual nature, documents fixing facts - the will of the subjects of law (General theory of state and law. Academic course in 3 volumes. Volume 2, 2002). Therefore, it is hardly possible to agree with the opinion of some scholars who argue that the legal framework includes only laws, decrees, resolutions of state authorities, orders, instructions and other regulatory documents of ministries, departments, organizations, local authorities (URL: Legal support, 2018).

However, to ensure the sustainable use of the animal world, it is necessary to have a set of measures in which legal regulation plays an important, but not the only role. The concept of legal support for the sustainable use of the animal world is a broader concept than legal regulation, since it includes not only a system of regulatory legal acts, but also a whole set of interrelated measures of an economic, organizational nature.

Another important means of ensuring the sustainable use of the animal world objects is the formation of an effective economic stimulation mechanism, which will ensure the implementation of environ- mental, economic and social interests of business entities.

The system of economic incentives operation is provided by special legislation of the Russian Federation. This includes, first of all, tax, banking, budget legislation. According to the Art. 473 of the Tax Code of the Russian Federation, only those categories of taxpayers whose activities are directly related to the use of the animal world are exempted from paying a fee for the right to use wildlife and biological resources (Tax Code of the Russian Federation of August 5, 2000).

However, for legal entities and citizens whose activities are not directly related to the use of objects of the animal world, but have a negative impact on them, tax concessions are not provided by law. For example, the activities of industrial enterprises, agricultural organizations cause great harm to the animal world, their habitat, as well as natural environmental systems. In its internal essence, the producers of goods are not interested in environmental protection, because economically and technically they can produce more products at lower costs if they do not spend money on environmental protection. Therefore, the task of introducing benefits on environmental taxes is to stimulate the enterprises to change the technological process in favour of environmental friendliness of production. Improving the environmental friendliness of production can be achieved, firstly, through the acquisition of treatment facilities. For enterprises, both fees and treatment facilities purchase lead to increased costs. Tax incentives in this case offset the additional costs of financing activities to reduce emissions. Secondly, for the production process in which a harmful substance is a necessary by-product, tax incentives can stimulate the substitution of the production of a non-environmentally friendly product for another, a more environmentally friendly one (Kireenko, Baturina, Golovan, 2014).

Noting the importance of economic incentives for the protection of wildlife, I consider it necessary to develop a mechanism for providing tax benefits to legal entities and citizens whose activities are not related to the use of wildlife. As a way of influencing the interests of business entities, I propose the following economic incentive measures that are aimed at the conservation and sustainable use of wildlife. It is advisable, firstly, to fix taxes at a higher rate in relation to industrial enterprises and agricultural organizations whose activity is not directly related to the use of wildlife, but cause great harm to wild animals and their habitats. The introduction of increased taxes will be aimed at reducing the number of enterprises that have a negative impact on the environment. Secondly, it is proposed to develop tax incentives (lowering the income tax rate) for those legal entities and individual entrepreneurs whose activity is focused on the conservation of wildlife and their 
habitats. Thirdly, an important economic incentive measure is to provide subsidies from the budget of the Russian Federation subject to those users of the animal world whose activity is aimed at restoring, preserving, increasing the number of individual species or their populations on the basis of data from state registration of wildlife objects.

The role of public administration in solving the problems of ensuring the sustainable use and protection of wildlife is great. The effective system of government regulation creation is one of the key activities of the state in the field of protection and use of wildlife. This fact has been repeatedly emphasized in regulatory acts which determine the main directions for the development of environmental legislation on the long term basis. Thus, in the Fundamentals of State Policy in the Field of Environmental Development of Russia for the Period until 2030, one of the first tasks to achieve the strategic goals of the state policy in the field of environmental development is the formation of an effective management system in the field of environmental protection and environmental safety, providing the interaction and coordination of government bodies activities.

The formation of a reliable and effective mechanism that can provide a balance of environmental, economic and social interests to meet the vital needs of the population is the main task of state administration in the field of protection and use of wildlife. Such a result is possible to be achieved only due to the centralization and systematization of state environmental protection management (Zhochkina, 2011). In order to streamline relations on the sustainable use of wildlife in the Russian Federation, a system of state bodies operates, the activities of which are aimed at fulfilling the requirements and conditions of the legislation on wildlife.

Sustainable use of the animal world is ensured through state registration of the number of objects of the animal world, as well as state monitoring and the state cadastre of objects of the animal world, planning, as well as federal state supervision in the field of protection, reproduction and use of wildlife objects and their environment and a number of other functions of management bodies provided by the legislation on the wildlife. Therefore, the content of legal support for the sustainable use of the animal world includes a system of organizational measures for such support.

A complex of organizational measures, without which the modern effective regulation of social relations in the field of sustainable use of the animal world seems impossible should be considered a part of legal support.

One of the efficient mechanisms of the biodiversity conservation is the development of the information and scientific support system, raising the educational level of government representatives and the public in the field of conservation and sustainable use of biological resources, ensuring public participation in re- solving issues in this area. Therefore, the main tasks are: to increase the role and effectiveness of environmental education and upbringing to form the ecological culture of the population; to form a responsible active citizens position in the field of biodiversity conservation; to develop a humane attitude towards wildlife and to spread environmental ethics (Ikonnikova, Kirillov, Nazarenko, 2015).

To achieve the effectiveness of information support, it is necessary: 1) to organize and hold press conferences, other information campaigns on the conservation and sustainable use of biodiversity, to organize speeches and broadcasts on television; 2) to publish and distribute visual aids; Internet information on conservation and sustainable use of biological resources, to develop stimulating and educational environmental programs for children and adolescents, to develop green modelling, to create websites informing on the activities of environmental organizations, on the availability of tourist and environmental routes.

Measures of ideological nature should include measures aimed at scientific justification, forecasting the social consequences of the operation of certain legal norms, theoretical development of the ways to overcome disagreements and the search for compromises (Arzamaskin, 2016) in the process of implementing legal norms in the field of sustainable use of wildlife.

Sustainable use of the wildlife is impossible without scientific support. The main tasks of the scientific support for the sustainable use of the wildlife include the following directions: the development and support of scientific research on the problems of conservation of wildlife objects, the results of which can stop the process of reduction of wild animals and the destruction of natural environmental systems; the development of a unified system of sustainability criteria in the use of wildlife; scientific support of the programs for the protection, reproduction and use of the wildlife.

Thus, the totality of means ensuring sustainable use of the wildlife includes: 1) legal means; 2) economic means aimed at stimulating subjects to preserve wild animals; 3) organizational means: monitoring of the animal world, accounting, supervision of the implementation of legislation on the animal world; 4) other means of ideological, informational, educational, scientific nature.

The United States, among the first states, actively supported the idea of sustainable use of natural resources as conservation through wise use (Clepper, 1966). Moreover, the implementation of projects on sustainable use took place with the wide participation of both scientists and ordinary citizens who advocated for the protection of natural resources. Therefore, in the 80 s of the XX century, some foreign countries, in addition to the basic laws on the wildlife, which determine the main provisions and criteria for the sustainable use of the wildlife, have 
started to develop programs for the sustainable use of the animal world objects.

The proponents of sustainable use name a number of successful programs which implement the principles of sustainable use of the wildlife and balance the interests of citizens, business and the state. An example of such is the Program developed by Garth Owen-Smith and implemented in the Kaokoveld desert in Northwest Namibia (Bonner, 1993). In particular, the program allowed to increase the incomes of the local population due to the development of ecotourism. According to Owen-Smith, The Purros program cost the villagers almost nothing, but generated a significant revenue for them (Krieps, 2019).

At the same time, the active and direct participation of people in the implementation of any sustainable use program is the most important principle of sustainable use. The local population support of sustainable use of the wildlife is important for achieving a successful result of any specific program. A project on the sustainable use and conservation of crocodiles was implemented in Australia. As a result, the annual income from the export of crocodile skins amounted to $\$ 340,000$. In addition, the project made it possible to provide jobs for the local population, which had 100 percent unemployment before the start of the project. The legal literature draws attention to the fact that sustainable use programs, which involve the local population in their planning and participation, lead to positive results, and in some cases, lead to the failure of more traditional environmental programs (Krieps, 2019). Thus, the practice of implementing programs for the sustainable use of the wildlife is particularly successful when it provides specific economic and social benefits to the local population.

Positive results were also achieved as a result of the implementation of the Program for the Sustainable Use of Natural Resources in Central Asia. The new policy on recognizing the value of wild animals by the local population through the practice of community management has yielded tangible results in the restoration of wild animals in large areas. Thus, the practice of community management was successfully introduced in Tajikistan, where after five years of environmental protection, the number of certain species of wildlife was restored and as a result, the local community began to receive environmental and economic benefits from this. In Kyrgyzstan, two community organizations were created, equipped and trained in the principles of management, monitoring and conservation of the wildlife. In accordance with the Program for the Sustainable Use of Natural Resources, the users were delegated the rights to manage wild animals and hunting lands. In Kazakhstan, thanks to the support of the political dialogue on the sustainable use of wildlife, a discussion has begun on existing problems and opportunities on privatization in the hunting sector. Thus, the practice of implementing various projects on the sustainable use of the wildlife in different countries makes it possible to balance the interests of the state and society.

At the same time, sustainable use of the wildlife provides a significant impetus to the economic and social development of remote underdeveloped rural areas. This conclusion was confirmed at the 2 nd International IUCN Congress, held in Amman in 2000, where it was stated that the sustainable use of the wildlife is an example of the legitimate use of natural resources not only in Central Europe, but throughout the world. Therefore, the needs of local communities that live through the use and conservation of biological diversity, as well as their impact, should be reflected in the fair distribution of the benefits arising from the use of resources, along with the contribution to its conservation.

Alongside with the strategic documents on sustainable use of the wildlife, ecological tourism is an effective way to implement the principles of sustainable development. In foreign countries, the potential of ecotourism as an effective tool for sustainable use is so high that at present many states, especially developing countries, include it in long-term plans for economic development. Ecotourism helps in the development of municipalities by providing an alternative source of livelihood for the local community. The purpose of ecological tourism is the conservation of wildlife, the sustainable use of wildlife, the preservation of the environment and also economic and social benefits (Anisimov, Ryzhenkov, 2014). Therefore, tourism can be sustainable if the development meets the needs of tourists and local people, protecting the biological diversity of the wildlife. Otherwise, use may lead to a reduction or even destruction of certain species of wild animals or their habitat. This happened in the Himalayas, when the number of tourists coming increased by more than 25 times. Local residents began to actively cut down forests - for fuel for campsites and numerous hotels. The ridges, several years ago buried in the thickets of rhododendrons, turned into barren wastelands, the paths were littered, and the populations of many animals and birds declined. In general, there are not so many absolutely positive examples of ecotourism development in the world. Rather, we can talk about the successful implementation of certain specific principles of ecotourism (Bochkareva, 2019). By the moment, ecotourism has become the basis of a number of important official international declarations. As a result, the norms of international acts in the field of sustainable tourism development have become effective tools in the process of implementing the principles of ecotourism.

In many countries, especially the developing ones, the volume of organized hunting tourism has rapidly increased over the past 50 years. Hunting tourism has numerous advantages for the host country and its rural population: conservation of ecosystems; income generation and job creation in poor and disadvantaged areas; economical and rational use of hab- 
itats unsuitable for agriculture or ordinary tourism; raising the awareness of the local population about the value of the animal world (otherwise hunting tourism is associated with harm, problems and expenses); less harmful impact on the environment than with other forms of tourism; a decrease in poaching, thanks to the joint efforts of all parties interested in generating revenue from hunting tourism (Baldus, Damm, Wollscheid, 2009). Thus, hunting tourism provides a significant positive impetus to the economic and social development of remote underdeveloped rural areas.

In general, we can conclude that Russian legislation contains a fairly wide range of effective legal measures to ensure the sustainable use of the wildlife, aimed at achieving a biological balance in nature, preserving ecological systems. Many of the examined foreign measures (the active involvement of interested citizens in the decision-making process related to the use of wildlife, and the involvement of local communities in wildlife management; the practice of implementing projects and programs for the sustainable use of certain species of wildlife) are of interest for the formation and improvement of the Russian legislation on the wildlife. Other provisions can be used in the comparative description for the formation of new ideas in the field of sustainable use of the wildlife.

\section{Sustainable Use of Rare, Endangered Spices: Arguments For and Against}

Biodiversity is the main environment-forming resource on the planet, providing the possibility of its sustainable development, preserving the living environment for humans and biological resources in general. Unfortunately, for many years the living nature of our planet was treated as a given, fulfilling rather aesthetic and psychological functions. Nowadays, in the period of annual growth in world production, increase in the number of people on the planet, and at the same time, growing awareness of the acuteness and need for global environmental protection measures, the attitude towards biodiversity as an integral part of nature is changing. In recent years, the heads of most states have signed a number of protocols and conventions aimed at preserving biodiversity. Significant amounts of money are spent annually on various activities related to the conservation of wildlife, unique places on the planet and the maintenance of various ecosystem functions, as well as environmental education (Myaskov, 2009). Further reduction of biodiversity can lead to the destabilization of biota, loss of integrity of the entire biosphere and individual ecosystems, in particular, their ability to maintain the most important environmental qualities necessary for life. As a result of the irreversible transition of the biosphere to a new state, it may be unsuitable for human life. Preserving the bi- odiversity of ecosystems on Earth is a necessary condition for human survival and the sustainable development of the civilization.

Rare and endangered species of animals, plants and mushrooms are the most fragile, but a very important part of biodiversity that needs priority in protection. The conservation priorities for such species are defined by the Convention on Biodiversity and Russian legislation, in particular the Strategy for the conservation of rare and endangered species of animals, plants and mushrooms. Rare and endangered species of animals, plants and mushrooms play an important role in various ecosystems and are the indicators of the natural ecosystems state (State Report, 2014). Due to the intense anthropogenic impact on the environment, the protection of rare and endangered species of animals remains particularly relevant.

The features characterizing various objects of the animal world are of great importance for the process of their sustainable use, and also for the mechanism of their legal regulation. Subjects enter into specific legal relations to satisfy different social interests and needs, realizing their subjective rights and obligations. Agitation should be mentioned among the main methods of protecting rare and endangered species of animals. The Analysis of domestic and foreign literature on the topic allows us to make a conclusion that the effectiveness of measures aimed at protecting nature is very high. Such measures should be focused on certain groups of population (taking into account age, professional, ethnic and other characteristics), most often in contact with endangered species and causing the greatest damage (Evstafiev, 2000). In our opinion, along with the public agitation, environmental education should be a powerful mechanism in the process of conservation of rare animal species.

It is necessary to form knowledge, experience and requirements for the conservation of rare animal species at all levels of education since early childhood. Legal informing of the population is also of great importance. It comprises reports on newly created natural reserves, on adding certain species into the Red Book, on filing special claims for the extraction of the spices. The conservation of rare and endangered species of animals is the task of the whole mankind. Therefore, all people and all civil society institutions should participate in the conservation of rare species of wild animals. In our opinion, the most important condition for the conservation of rare species of animals is a responsible, competent attitude of people to these animals and to their natural habitats. The study of biological diversity and the protection of rare species require a high environmental and scientific culture, which implies the existence of a system of environmental and scientific education.

The proponents of sustainable use state that there is a need for some changes, especially since the CITES Convention does not work for many species, which 
are at risk of extinction, although its developers intended to protect them. The question of the priority of some sustainable use programs over their analogues of nature conservation programs remains debatable. Since the benefits come from protecting species, such programs are usually less expensive than other conservation programs (Gerstenzang,1994). Moreover, the costs of conservationists to combat poaching cannot be measured only in monetary terms. For example, anti-poaching associations of Zimbabwe National Parks have killed 167 poachers since 1984, while 4 police officers were killed and 8 more injured during the same period. In addition, at the same period of time, Zimbabwe lost 300 rhinos in 2 years, despite a strict conservation policy. In this way, sustainable use programs, providing a viable alternative to poaching, can help reduce human losses (Tyson, 1993). The last costs included in conservation programs are those incurred by communal and private landowners, many of whom are subsistence farmers. For example, these landowners are not protected from elephants, who can roam freely around their lands and trample their fields. While tourists enjoy the sight of elephants walking, one hundred miles away from this place, elephants can walk along the fields of farmers, destroying crops and threatening human lives. Residents of several countries criticize CITES and other protection programs for their inability to solve such social and economic issues as the damage caused by endangered species to people living in the neighbourhood. Sustainable use programs avoid this kind of criticism by providing reasonable benefits to residents of several countries who bear the burden of costly invasion of endangered species that they must protect.

Like many other treaties, CITES often gives rise to conflicts between richer nations, which usually hold a position in support of the nature conservation concept, and financially poor but rich in resources developing nations. Perhaps for these reasons, the Director of the Africa Environmental Program recognizes the right of developing nations for sustainable use a vital for the long-term functioning of CITES, as well as the principle of paramount importance of nature conservation throughout Africa (Cone, 1994). The opponents of sustainable use speak out against this policy for a number of reasons. Perhaps the most fundamental problem is the need to define the authorities, able to determine which use of which endangered species should be considered sustainable. Taking into consideration the difficulties in defining such fundamental concepts as spices or sample within CITES, it seems unlikely that all parties will be able to agree on a common definition of sustainable use. However, such a definition was formulated as part of the CITES export permit requirements in Articles III and IV, which stipulate that sustainable use is an activity that is not ... harmful to the survival of the species involved in it (The United Nations Convention on International Trade in Endangered
Species of Wild Fauna and Flora, 1973). Thus, within CITES, the category of sustainable use can already be applied to Appendix II on species to a limited extent.

The opponents of this concept claim that because of the emphasis on the use of species for utilitarian purposes, sustainable use seeks to protect only those species that currently have economic value (Freese, Saavedra, 1991). Such detractors are worried that if wildlife has no value, then wild animals and their habitat will be destroyed in order to clear the place for other land users. This problem is especially acute for those species that do not have obvious use. Examples include species that are not commonly used for consumption, such as many species found in endangered rainforests that are threatened with extinction due to loss of habitat before their value can be discovered. This problem may concern more wellknown species, especially those species which are in such a critical position that any consumer use is not sustainable. A similar problem applies to those species whose breeding rate is slow even under optimal conditions. However, sustainable use does not require any of the above species to be exposed to a greater risk than already exists. Non-consumer use, such as ecotourism, will not exacerbate existing problems. Moreover, sustainable use programs will not only help protect the habitat of endangered species, but also entire ecosystems, including those spices which are less vulnerable to protection (Booth, 1993).

Perhaps, for some types of problematic species, not much will change if CITES allows the sustainable use of endangered species. These cases illustrate limitations in which the category of sustainable use may not have much effect on problems arising from CITES nature conservation programs. For example, it is likely that sustainable use of endangered species will have a limited effect on some of the current CITES problems, including cross-border poaching. A lack of funding for anti-poaching patrols, the high cost of animals, and the low risk of punishment provoke poachers to violate CITES regulations (Gerstenzang, 1994).

CITES is not an agreement supporting wildlife use and trade. The Convention provisions are aimed at regulating trade by introducing restrictions. It limits the principle of free circulation so that international trade does not lead to the extinction of species. CITES is often regarded as an international instrument for the biodiversity protection rather than an international trade agreement. The need to adopt this document was strongly connected with the fact that international trade in representatives of wild fauna and flora is one of the reasons for the decline in populations of many animals and plants. Since CITES entered into force, not one of the 30 thousand species of flora and fauna under its protection has disappeared (Kopylov, Merkulov, 2013). 
Another important issue facing endangered species is habitat loss or degradation, as well as related issues, including the rapid growth of the human population and the introduction of exotic species. Regardless of the existence of sustainable use programs, CITES can do little to directly control the threats arising from these and other factors that are essentially outside its scope.

The proponents of sustainable use, however, claim that sustainable use programs provide and promote knowledge about endangered species, their value, and thus indirectly help alleviate issues not related to international trade. Since sustainable use has the potential to increase the caring attitude and concern of local people for endangered species, the existence of problems not related to sustainable use should not in itself prevent the introduction of sustainable use programs.

\section{Conclusion}

Interpretation of sustainable use of wildlife as a process of realization by the subjects of their rights and obligations allows us to study this concept in relation to a set of legal support measures, the implementation of which allows to achieve conservation of the biological diversity, formation of requirements for the sustainable existence and reproduction of wildlife, conservation of its genetic fund. Since the role and importance of legal support measures for the sustainable use of wildlife at the present stage is increasing in solving social, economic, and environmental problems, the study of legal support measures for the sustainable use allows, firstly, to determine the effectiveness of the legal impact on subjects; secondly, to identify the most effective means that should be applied to ensure a balance of private and public interests; thirdly, to examine carefully the problems of sustainable use. The measures of legal support for sustainable use of the wildlife presented by the author determine the conditions that should be met in order to confirm that the objects of the animal world are used sustainably.

\section{References}

1. ANISIMOV A.P., RYZHENKOV A.J., 2014, Ecotourism Development, in: Environmental Policy and Law, 44(6), p. 545-565.

2. ARZAMASKIN A.N., 2016, Definition of the concept 'legal support' statement of the problem, in: Science and School, 6, p. 50.

3. BALDUS, R. D., DAMM, G. R. AND L. WOLLSCHEID, 2009, Sustainable hunting tourism: position of the CIC Commission on Tropical Wildlife, in Best Practices for the Sustainable Use of Hunting Animals, http://www. cic-wildlife.org/wp-content/uploads/2013/04/ Technical_series_1_RU.pdf (16.03.2019)

4. BOCHKAREVA T.V., Ecotourism: analysis of existing international experience, http://tourlib. net/statti_tourism/bochkareva.htm (25.05.2019).
5. BONNER R., 1993, At The Hand Of Man: Peril and Hope for Africa's Wildlife, Vintage, New York.

6. BOOTH W., 1993, Bag a Gator and Save the Species, Environmentalists Link Habitat Preservation to Sales of Skins, in: Washington Post, Aug 25.

7. CLEPPER H., 1966, The Conservation Movement Birth and Infancy, in: Origins of American conservation, Clepper H. ed., Ronald Press, New York.

8. CONE M., 1994, Conflict Marks Endangered Species Treaty, in: L.A. Times, A26.

9. DECREE OF THE GOVERNMENT OF THE RUSSIAN FEDERATION No. 13, dated June, 1997, On the Approval of the Rules for the Taking of Fauna Belonging to Species Listed in the Red Book of the Russian Federation, with the Exception of Aquatic Biological Resources, (R.E. from 05.06.2013), «Consultant Plus» computerbased legal research system (25.01.2018).

10. DECREE OF THE PRESIDENT OF THE RUSSIAN FEDERATION No. 236, dated February 4, 1994, On the National Strategy of the Russian Federation for Environment Protection and Sustainable Development, «Consultant Plus» computer-based legal research system (26.01.2018).

11. DECREE OF THE PRESIDENT OF THE RUSSIAN FEDERATION No. 440 dated April 1, 1996, On the Concept of Transition of the Russian Federation towards Sustainable Development. «Consultant Plus» computer-based legal research system (26.01.2018).

12. DECREE OF THE GOVERNMENT OF THE RUSSIAN FEDERATION No. 559, dated May 8, 1996, On Development of the Draft National Strategy for Sustainable Development of the Russian Federation, "Consultant Plus» computer-based legal research system (26.01.2018).

13. EVSTAFIEV V.A., 2000, Legal framework and practical mechanisms for conservation of rare species, Publishing house Ima-Press, p. 23.

14. FEDERAL LAW No. 209-FZ, dated July 24, 2009, On Hunting and Conservation of Hunting Resources and on Amending Certain Legislative Acts of the Russian Federation, «Consultant Plus») computer-based legal research system (29.01.2018).

15. FEDERAL LAW No. 7-FZ, January 10, dated 2002, On Environmental Protection, «Consultant Plus» computer-based legal research system (26.01.2018).

16. FEDERAL LAW OF THE RUSSIAN FEDERATION No. 52-FZ, dated April 24, 1995, On Wildlife, «Consultant Plus» computer-based legal research system (26.01.2018).

17. FREESE C.H., SAAVEDRA C.J., 1991, Prospects for Wildlife Management in Latin America and the Caribbean, in: Neotropical Wildlife Use and Conservation, eds. Robinson J., Redford K., Chicago University Press, Chicago, p. 430-431.

18. GENERAL THEORY OF STATE AND LAW. ACADEMIC COURSE IN 3 VOLUMES. VOLUME 2, 2002, M: ICD Mirror-M, p. 496. 
19. GERSTENZANG J., 1994, U.S. Will Impose Trade Sanctions Against Taiwan to Protect Wildlife, in: L.A. Times.

20. IKONNIKOVA M.A., KIRILLOV A.V., NAZARENKO A.V., 2015, Factors determining the effectiveness of environmental education, in: Pedagogical, psychological and biomedical problems of physical education and sport, 37(4), p. 102-104.

21. KALININ I.B., 2003, Rational Use of Natural Resources and Protection of Environment as a Basis for Sustainable Use of Natural Resources, in: Tomsk State University Bulletin, 279, p. 4851.

22. KHARKOV V.N., 2015, Legal Support of Public Participation in Environmental Management and Environmental Protection, in: Regional Aspect // Izvestiya, Tula State University, Ecological and Legal Sciences, 2(2), p. 111.

23. KIREENKO A.P., BATURINA O.V., GOLOVAN S.A., 2014, The use of tax benefits in environmental regulation: foreign experience and prospects in Russia, in: Bulletin of the Irkutsk State Economic Academy, 1, p. 25-33.

24. KOLBASOV O.S., 1982, International legal environmental protection, in: International Relations, p. 130.

25. KOLBASOV O.S., 1980, Property Right in Wildlife, in: Development of Agrarian and Legal Sciences, Moscow, p. 61-62.

26. KOPYLOV M.N., MERKULOV K.A., 2013, 'Pros' and 'cons' of CITES: on the anniversary of the convention, in: Legal Initiative, 7, p.18.

27. KRIEPS C.L., Sustainable use of endangered species cites: is it a sustainable alternative?, https://www.law.upenn.edu/journals/jil/articles/volume17/issue1/Krieps17U.Pa.J.Int\%2 (21/06/2019).

28. MARCHENKO. M., 2001, Problems of theory of state and law, Publishing House Prospect, Moscow, p. 354

29. MONCRIEFFE J., LUTTRELL C., 2005, Analytical framework for understanding political economy of sectors and policy arenas, https://www.odi.org/sites/odi.org.uk/files/odiassets/publications-opinion-files/3898.pdf.

30. MYASKOV A.V., 2009, Relevance of biodiversity conservation as a basis of natural ecosystems, in: Mountain Information and Analytical Bulletin (scientific and technical journal), 6(12), o. 263.

31. RUSSIAN FEDERATION GOVERNMENT RESOLUTION No. 212-P, dated February 17, 2014, On the Strategy for the Conservation of Rare and Endangered Species of Animals and Plants and Development of Hunting Activities in the Russian Federation until 2030, «Consultant Plus» computer-based legal research system (29.01.2018).
32. SANCHEZ-BAYOA WYCKHUYSBN K.G., 2019, Worldwide decline of the entomofauna: A review of its drivers, in: Biological Conservation, 232, p. 2-27.

SAPUN V.A., 1992, The instrumental theory of law in legal science, in Modern State and Law. Questions of theory and practice, Vladivostok, p. 20.

33. STAINOV P., 1974, Legal Issues of Nature Protection, ed. Kolbasova O.S., Progress Publishing House, Moscow, p.21-22.

34. STATE REPORT, 2014, On the State and Protection of the Environment in the Russian Federation in 2014, http://www.mnr.gov.ru (26.01. 2018).

35. STATE REPORT, 2016, On the State and Protection of the Environment in the Russian Federation, p. 196, http://www.mnr.gov.ru/docs/ (27. 08.2019).

36. STUDY, 2016, Humans to Wipe out Two-Thirds of Wildlife by 2020, https://new.wwf.ru/resources/news/klimat-i-energetika/k-2020-godumir-poteryaet-dve-treti-dikikh-zhivotnykh/ (25.01.2018).

37. Tax Code of the Russian Federation of August 5, 2000, Part 2, N 117-Ф3, «Consultant Plus» computer-based legal research system (15.03. 2019).

38. TORIA R.A., 2016, Legal Regulation of Financial Provision of Small Indigenous Peoples of the North, Siberia and the Far East, ed. Gracheva E. Yu., Prospekt Publishing House, Moscow, p. 3-4.

39. TYSON R., 1993, Herds Pay Highest Price, in: Det. Free Press, 1.

40. URL: Legal support, 2018, http://www.centeryf.ru/data/Yuristu/Pravovoe-obespechenie.php (19.08.2018)

41. UN, 1973, The Convention On International Trade in Endangered Species of Wild Fauna and Flora, Washington, 3 March, «Consultant Plus» computer-based legal research system (29.01.2018).

42. VOLIANSKY E.V., 2014, Normative-Legal Aspects of State Regulation for Hunting and Hunting Resources, in: Economics. State, Society, http://ego.uapa.ru/en/issue/2014/01/01/ (29.01.2018).

43. WEBB G., 2002, Conservation and sustainable use of wildlife - an evolving concept, in: Pacific Conservation Biology, 8, p. 12-26.

44. WWF, 2016, Living Planet Report, http://wwf. panda.org/about_our_earth/all_publications /lpr_2016/ (25.01.2018).

45. ZHOCHKINA I.N., 2011, Current state and development prospects of the environmental governance system in the regions (the Republic of Mordovia), in: Environmental Law, 6, p. 26. 